Tiến sĩ Vương Quân Hoàng tác giả chương sách đại diện cho nền kinh tế và tài chính Việt Nam

Trường ĐH Phenikaa

12 February 2019

Tin tức Phenikaa University

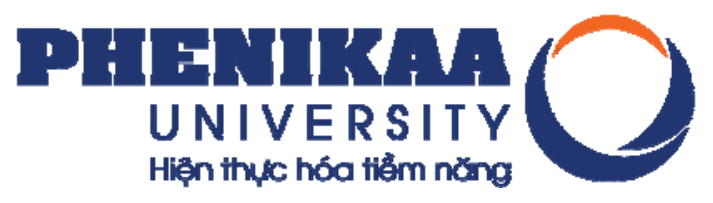

https://phenikaa-uni.edu.vn/chitiet/su-kien/tien-si-vuong-quan-hoang-tac-giachuong-sach-dai-dien-cho-nen-kinh-te-va-tai-chinh-viet-nam 


\section{Tiến sĩ Vương Quân Hoàng tác giả chương sách đại diện cho nền kinh tế và tài chính Việt Nam}

$12 / 02 / 201911: 55 \mathrm{CH}$

$+2$

Tháng 01/2019, TS. Vương Quân Hoàng - Giám đốc Trung tâm nghiên cứu khoa học xã hội liên ngành (ISR), Trường Đại học PHENIKAA, đã công bố chương sách đại diện cho nền kinh tế và tài chính Việt Nam, đăng tải trong cuốn "Routledge Handbook of Banking and Finance in Asia" (ISBN: 9781315543222) do một trong những nhà xuất bản uy tín nhất thế giới về khoa học xã hội Routledge (Taylor \& Francis) và Ngân hàng Phát triển Châu $A(A D B)$ cùng phát hành. Đây là một vinh dự rất lớn cho TS. Vương Quân Hoàng nói riêng và Trường Đại học PHENIKAA nói chung, vì $\mathrm{ADB}$ chỉ lựa chọn 01 tác giả duy nhất, cho 01 chương duy nhất về Việt Nam trong số 18 nền kinh tế năng động ở Châu Á.

Cuốn sách "Routledge Handbook of Banking and Finance in Asia" này tổng hợp bài viết của các học giả, nhà hoạch định chính sách và các nhà thực hành hàng đầu khu vực để cung cấp một hướng dẫn toàn diện và tiên tiến cho các tổ chức tài chính, thị trường và hệ thống của châu Á.

Phần I của cuốn sách cung cấp cái nhìn tổng quan về ngân hàng và tài chính ở Đông, Đông Nam và Nam Á, bao gồm các ví dụ từ các nước như: Cộng hòa Nhân dân Trung Hoa; Ấn Độ; Nhật Bản; và Singapore. Phần II bao gồm các chương theo chủ đề, bao gồm các chủ đề như ngân hàng thương mại, ngân hàng phát triển, tài chính cơ sở hạ tầng, thị trường chứng khoán, bảo hiểm và quỹ tài sản có chủ quyền. Nó cũng bao gồm kiểm tra các quy định và giám sát ngân hàng, và phân tích các quy định vĩ mô, các biện pháp quản lý dòng vốn và chính sách tiền tệ. Cuối cùng, nó cung cấp những hiểu biết mới về các vấn đề thời sự như doanh nghiệp vừa và nhỏ, tài chính xanh và Hồi giáo. Cuốn cẩm nang này được coi là một tài nguyên thiết yếu cho các học giả và sinh viên kinh tế và tài chính châu Á và cho các chuyên gia làm việc trong thị trường tài chính ở châu Á.

Chương sách đại diện cho nền kinh tế và tài chính Việt Nam nằm ở Phần I - chương thứ 12 có tên gọi: Nền kinh tế tài chính của Việt Nam trong thời đại cải cách (1986 - 2016 ). Trước cuộc cải cách Đổi mới năm 1986, nền kinh tế của Việt Nam bị tàn phá sau 30 năm chiến tranh với hai cường quốc quân sự là Pháp và Hoa Kỳ, kết thúc vào năm 1975. Trong 10 năm sau đó, Việt Nam đã từng gánh chịu nhiều thất bại trong các thử nghiệm về kinh tế, bao gồm cả hợp tác nông nghiệp, cải tạo công thương, cải cách giá-lương-tiền, trong cơ chế tập trung quan liêu-bao cấp. Những thất bại đó đã kéo tổng sản phẩm quốc nội bình quân đầu người (GDP) giảm xuống 97 USD vào năm 1989 trong khi tỷ lệ nợ nước ngoài so với GDP lên đến 330\%._Nền kinh tế suy yếu và trở thành một trong những nước nghèo nhất thế giới ( VGP 2016 ). Sự bứt phá kinh tế suốt 3 thập kỷ kể từ đó đã chuyển biến đất nước toàn diện, trở thành quốc gia có mức thu nhập trung bình (LMIC) và nền kinh tế thị trường năng động, đồng thời cũng ghi đậm nét dấu ấn của sự đóng góp lớn lao của các doanh nghiệp kinh tế tư nhân, cũng như vai trò của thị trường vốn và tiền tệ.

Việc Taylor \& Francis và Ngân hàng Phát triển Châu Á (ADB) lựa chọn TS. Vương Quân Hoàng là tác giả duy nhất biên soạn chương sách viết về nền kinh tế và tài chính Việt Nam đã cho thấy tầm ảnh hưởng và uy tín của TS. Vương Quân Hoàng nói riêng và Trung tâm ISR, Trường Đại học PHENIKAA nói chung trong lĩnh vực nghiên cứu KHXH\&NV tại Việt Nam. 


\section{GIÁO DỤC}

\section{KHOA HỌC - CÔNG NGHẸ}

ĐớN V! TRỰC THUộC

\section{THÔNG TIN}

\section{TRƯờNG ĐẠI HỌC PHENIKAA}

• Phường Yên Nghĩa - Quận Hà Đông - Hà Nội

C 024.62918118 | Hotline: 094.651 .1010

$\checkmark$ Info@phenikaa-uni.edu.vn

\section{$f$ in 1000}

\section{Đại học PHENIKAA}

Xem bản đồ lớn hơn

Đại học PHENIKAA
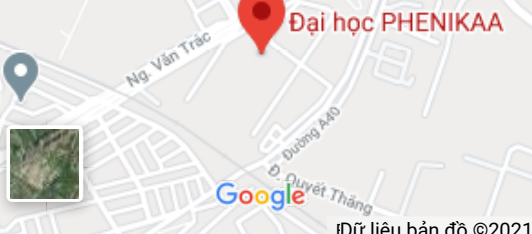